\title{
Experimental Study for the Embedded Depth of Support Structure Foundation Pit in Granite Residual Soil Area
}

\author{
Yi-ao Liu $\left(\mathbb{D},{ }^{1}\right.$ Chang-ming Wang $\left(\mathbb{D},{ }^{1}\right.$ Rui-yuan Gao, ${ }^{1}$ Bai-long Li, ${ }^{1}$ Xiao-yang Liu, ${ }^{1}$ \\ Zhu Liang, ${ }^{1}$ Nan Jiang, ${ }^{1}$ and Zhi-dong Chen ${ }^{2}$ \\ ${ }^{1}$ College of Construction Engineering, Jilin University, Changchun 130012, China \\ ${ }^{2}$ Shenzhen Hongyeji Geotechnical Science \& Technology Co., Ltd., Shenzhen, Guangdong 518000, China \\ Correspondence should be addressed to Chang-ming Wang; wangcm@jlu.edu.cn
}

Received 4 November 2020; Revised 26 November 2020; Accepted 3 December 2020; Published 24 December 2020

Academic Editor: Chun Zhu

Copyright (c) 2020 Yi-ao Liu et al. This is an open access article distributed under the Creative Commons Attribution License, which permits unrestricted use, distribution, and reproduction in any medium, provided the original work is properly cited.

In order to deeply understand the appropriate embedded depth of the foundation pit diaphragm wall in granite residual soil area, a physical model of the diaphragm wall with inner support for foundation excavation was constructed according to the actual project in the proportion of $1: 30$. The distribution of Earth pressure, the horizontal displacement of the wall, and the settlement behind the wall were obtained by physical experiments. The numerical simulation was then performed to authenticate the results from physical modeling. It was observed that the embedded depth of the diaphragm wall had the most obvious influence on the horizontal displacement of the wall. Moreover, the final soil settlement and its influence were significantly increased with the decrease in embedded depth. The analysis results also suggested that the control value for the embedded depth of the wall should not be less than $0.36 \mathrm{H}$ ( $H$ is the excavation depth of the foundation pit).

\section{Introduction}

More excavation support problems related to underground space engineering are highlighted with the increasing contradiction between the rapid development of cities and the lack of land resources in China. The granite residual soil is widely distributed in the south of China, and the diaphragm wall has been used in this area due to its high efficiency and safety under the condition that the foundation pit is developing superlarge and ultradeep. The diaphragm wall plays a critical role in the support structure which accounts for $70 \%-80 \%$ of the total support structure costs [1]. Therefore, appropriate control of the embedded depth of the diaphragm wall is of great significance for engineering construction.

In the past 40 years, predecessors carried out further studies about the foundation pit in the granite residual soil area. The development of foundation pit support technology in Shenzhen can be divided into four stages: unconscious application, initial application of various technologies, soil-nail wall era, and rational application of various technologies [2]. After approximately 40 years of development, the foundation pit project in Shenzhen has moved toward the fifth stage, which focuses on deformation control [3]. Nowadays, the diaphragm wall has been widely used in Shenzhen as a kind of excavation engineering technology due to its safety, quality, impermeability, and minimized environmental impact $[4,5]$. Wang and Liu [6] collected the deformation data of 13 granite residual soil foundation pits in the south of China, combined with the existing statistical results of foundation pit deformation in other areas of China, and made a comparative analysis of the deformation characteristics of deep foundation pits in this area. Bai et al. [7] took a foundation pit in Guangzhou as an example to study the effect of embedded depth on the deformation of the diaphragm wall and found that the horizontal displacement of the diaphragm wall gradually decreases as the embedded depth increases. At present, it can be widely recognized that if the embedded depth is shallower, the 
horizontal displacement of the diaphragm wall is too large, and the foundation pit can be easily destabilized; if the embedded depth is very large, it is very likely to construct the embedded section into the rock stratum with low weathering, which will cause great difficulties for the construction, and the engineering cost will significantly increase. At this time, the effect of increasing the embedded depth on deformation control of the foundation pit is not obvious.

In order to deeply understand the influence of the diaphragm wall embedded depth of the foundation pit in the granite residual soil area, this study made a physical test model according to a similar theory with two similar soil materials: granite residual soil and fully weathered granite. The whole process of the deep foundation pit excavation with the inner support system was simulated, and numerical simulation was used to compare the changes in the physical model experiment.

\section{Scale Similarity and Physical Model}

2.1. Scale Similarity. The main requirements for the similarity of the physical model experiment are as follows: the boundary conditions of the model, geometry, density, strength, and stress changes of similar materials should follow certain similar laws. The ratio of physical quantities with the same dimensions between the prototype and the model is called a similar scale and is represented by $C$. The geometric similarity coefficient generally determines first when conducting a similar model experiment. The geometric similarity coefficient is $C_{i}=n$, and the density similarity coefficient is $C_{y}=1$. According to the dimensional analysis method, it should be known that the physical quantities of the same dimension are similar to scale $C$ as follows:

$$
\begin{gathered}
C_{y}=C_{\varphi}=C_{\mu}=C_{g}=1, \\
C_{o}=C_{l}=C_{E}=C_{\sigma}=n,
\end{gathered}
$$

where $C_{y}$ is the similarity scale of density, $C_{\varphi}$ is the similarity scale of internal friction angle, $C_{\alpha}$ is the similar scale of Poisson's ratio, $C_{g}$ is the similarity scale of strain, $C_{o}$ is the similarity scale of cohesion, $C_{E}$ is the similarity scale of elastic modulus, and $C_{\sigma}$ is the similar scale of stress.

\subsection{Engineering Prototype}

2.2.1. Project Overview. The proposed site is located at No.1, Tairan 7th Road, Chigongmiao Industrial Zone, Futian District, Shenzhen City. It is adjacent to Tairan 8th Road on the north side and Binhe Avenue on the south side. Shenzhen Metro Line 9 passes near the site and the nearest station is about $41 \mathrm{~m}$ from the study site. The west side is Tairan 9th Road, and the east side is another construction project. The overall terrain of the proposed site is relatively flat, with a construction land area of $5,775.05 \mathrm{~m}^{2}$. The site is planned for the business center, with 4 basement floors. The foundation pit site and research scope are shown in Figures 1 and 2, respectively.

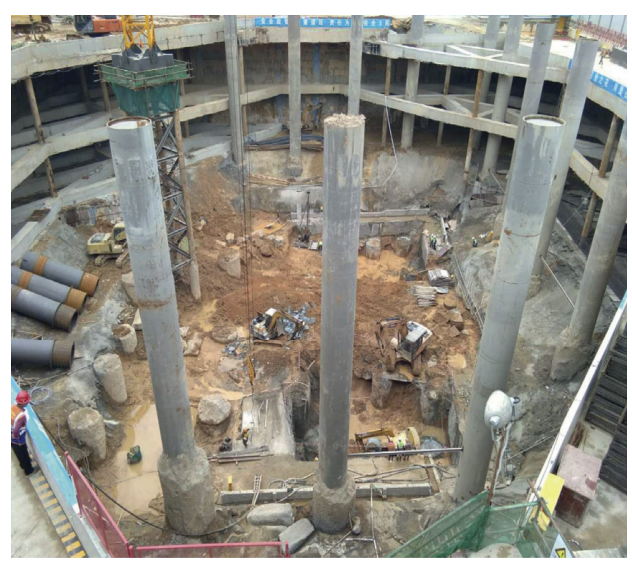

FIgURE 1: Overview of the excavation.

According to the current drilling, the stratum in the site from top to bottom is as follows: the newly deposited artificial filling soil $\left(Q_{4}{ }^{\mathrm{ml}}\right)$, the new commission sea-land interaction sediments $\left(Q_{4}{ }^{\mathrm{mc}}\right)$, the diluvium layer $\left(Q 3^{\mathrm{al}+\mathrm{pl}}\right)$, the Quaternary eluvium $\left(Q^{\mathrm{el}}\right)$, and the underlying bedrock of early Cretaceous coarse-grained granitic of the Yanshanian $\left(\lambda \beta^{5} K_{1}\right)$. The composition of the site foundation soil is shown in Table 1 .

\section{Design of Support Structure}

The excavation depth of the foundation pit is $19.3 \mathrm{~m}$, the plane figure is approximately rectangular, the length is $77.9 \mathrm{~m}$, and the width on both sides are $63.5 \mathrm{~m}$ and $75.4 \mathrm{~m}$, respectively. The diaphragm wall is $1 \mathrm{~m}$ in width and $28.3 \mathrm{~m}$ in length with the impermeability grade of S8. A reinforced concrete crown beam is set on the top of the wall with section size $b \times h=1 \mathrm{~m} \times 1 \mathrm{~m}$. Three reinforced concrete inner supports are set in the middle with the cross-sectional size of $b \times h=1 \mathrm{~m} \times 1 \mathrm{~m}$, and the distances between the supports from top to bottom are $7.3 \mathrm{~m}$, $5.1 \mathrm{~m}$, and $6.4 \mathrm{~m}$, respectively. The vertical support is a steel pipe column, the upper half of which is $600 \mathrm{~mm}$ in diameter and $16.9 \mathrm{~m}$ in length and the lower half is $1000 \mathrm{~mm}$ in diameter and $15.6 \mathrm{~m}$ in length. The concrete grade of the diaphragm wall, crown beam, and waist beam is $C 30$, the concrete strength grade of the cushion is $C 15$, and the strength grade of column steel is $Q 235$. The thickness of the reinforced protective layer of the diaphragm wall is $50 \mathrm{~mm}$. The thickness of the reinforced protective layer in inner support is $35 \mathrm{~mm}$. The profile of the foundation pit is shown in Figure 3.

3.1. Physical Model. The foundation pit support scheme is composed of a diaphragm wall with an inner support structure. During the physical modeling experiments, considering the symmetrical shape of the foundation pit and the supporting structure in the foundation pit, a quarter of the foundation pit is assessed by the physical simulation experiment. The area under study for this experiment is shown in Figure 2. 


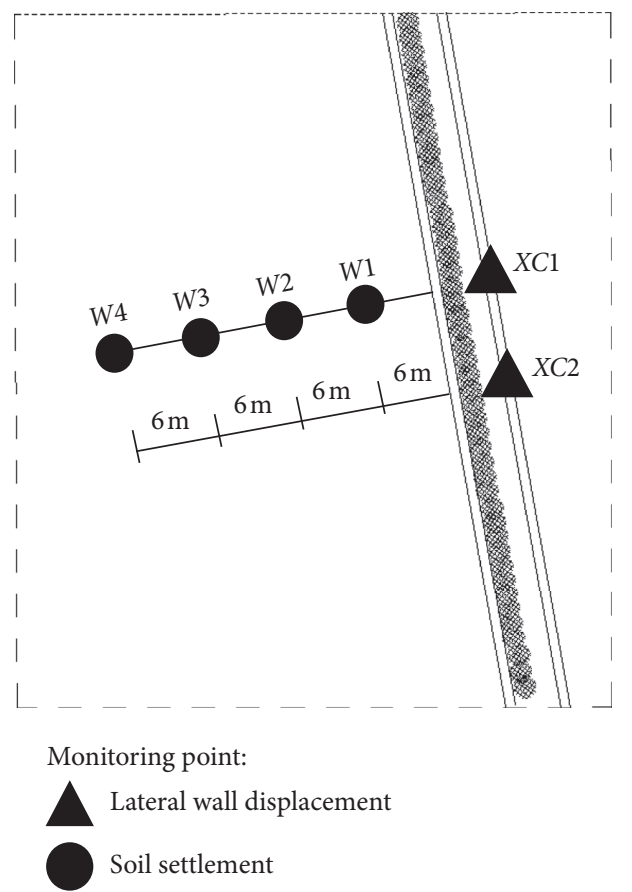

(a)

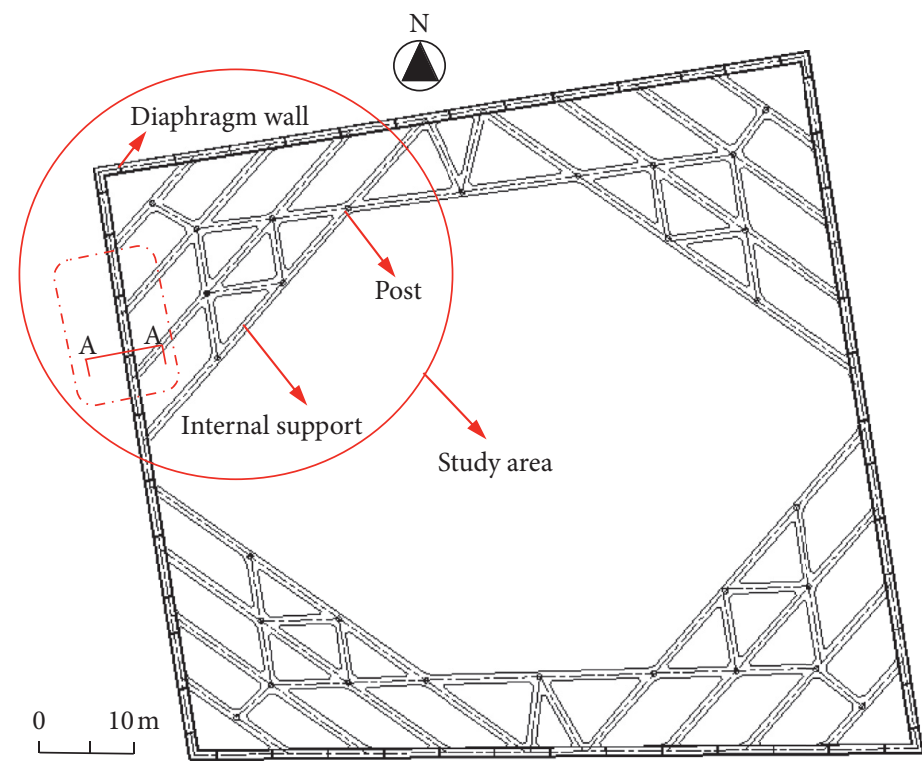

(b)

FIgURe 2: Diagram of the foundation pit. (a) Diagram of monitoring points. (b) Diagram of foundation pit study area.

TABLE 1: The information of soil used.

\begin{tabular}{|c|c|c|c|}
\hline \multicolumn{2}{|c|}{ Stratum } & \multirow{2}{*}{$\begin{array}{l}\text { Average } \\
\text { thickness (m) }\end{array}$} & \multirow{2}{*}{ Lithology characteristics } \\
\hline Period & Epoch & & \\
\hline \multirow{4}{*}{$\begin{array}{l}\text { Quaternary } \\
\text { period }\end{array}$} & Holocene $\left(Q_{4}{ }^{\mathrm{ml}}\right)$ & 6.3 & $\begin{array}{l}\text { It comprises the tawny clay and brown maroon sand with the coarse side and } \\
\text { hardpan strata. And, it is slightly wet, mostly slightly dense state, locally loose state, } \\
\text { or moderately dense. }\end{array}$ \\
\hline & Holocene $\left(Q_{4}{ }^{\mathrm{mc}}\right)$ & 3.0 & $\begin{array}{l}\text { It mainly comprises the cinereous clay with a small amount of organic matter. The } \\
\text { cut surface is smooth with a slight gloss. And, it contains the gravel with lens shape } \\
\text { once in a while. }\end{array}$ \\
\hline & $\begin{array}{l}\text { Pleistocene } \\
\left(Q_{3}{ }^{\text {al }+\mathrm{pl}}\right)\end{array}$ & 1.7 & $\begin{array}{l}\text { The primary color is tawny, and the brown maroon color, greyish color, etc., are } \\
\text { partly distributed on it. And, it mainly comprises sandy clay, clayey sand gravel, } \\
\text { and clayey sand. }\end{array}$ \\
\hline & $\begin{array}{l}\text { Pleistocene } \\
\quad\left(Q_{3}{ }^{\mathrm{el}}\right)\end{array}$ & 11.2 & $\begin{array}{l}\text { The color is greyish and brown. The weathered host rock is mainly medium-coarse- } \\
\text { grained granite, the structure of the host rock is clearly visible, gravel sand accounts } \\
\text { for about } 25 \% \text {, and the composition is quartz. }\end{array}$ \\
\hline \multirow[t]{2}{*}{ Cretaceous } & $\begin{array}{l}\text { Yanshanian } \\
\left(\lambda \beta^{5} K_{1}\right)\end{array}$ & 5.1 & $\begin{array}{l}\text { The primary color is yellowish-brown and reddish-brown. The rock is weathered } \\
\text { violently, and the organizational structure has been basically destroyed, but it is still } \\
\text { recognizable. The core is in the shape of a hard soil column, which is easy to } \\
\text { disintegrate when exposed to water. }\end{array}$ \\
\hline & $\begin{array}{l}\text { Yanshanian } \\
\left(\lambda \beta^{5} K_{1}\right)\end{array}$ & 14.4 & $\begin{array}{l}\text { The primary color is brown-yellow, gray-brown, the rock is weathered strongly, the } \\
\text { organizational structure has been partially destroyed, and it disintegrates in water }\end{array}$ \\
\hline
\end{tabular}

\section{Test Methods}

4.1. Test Scheme. Previous research shows that the influence of dry density and moisture content of the material on its properties was rarely considered when preparing similar materials [8-10]. Therefore, on the basis of previous research findings, this study has taken quartz sand and bentonite as raw materials, weight ratio of sand and bentonite, dry density, and moisture content as three influencing factors, set up 4 levels, and designed a total of 16 groups of orthogonal tests to conduct the preparation research of similar materials. According to the orthogonal test results, a large number of tests were carried out under the conditions of changing parameters, and finally, two similar materials of simulated granite residual soil and fully weathered granite used in the physical experiments were obtained. In addition, the soil layer above the gravelly clayey soil was simulated by fully weathered granite residual soil. The particle size range of quartz sand was $1 \mathrm{~mm}$ to $2 \mathrm{~mm}$. The deformation modulus $E_{0}$ is as follows: 


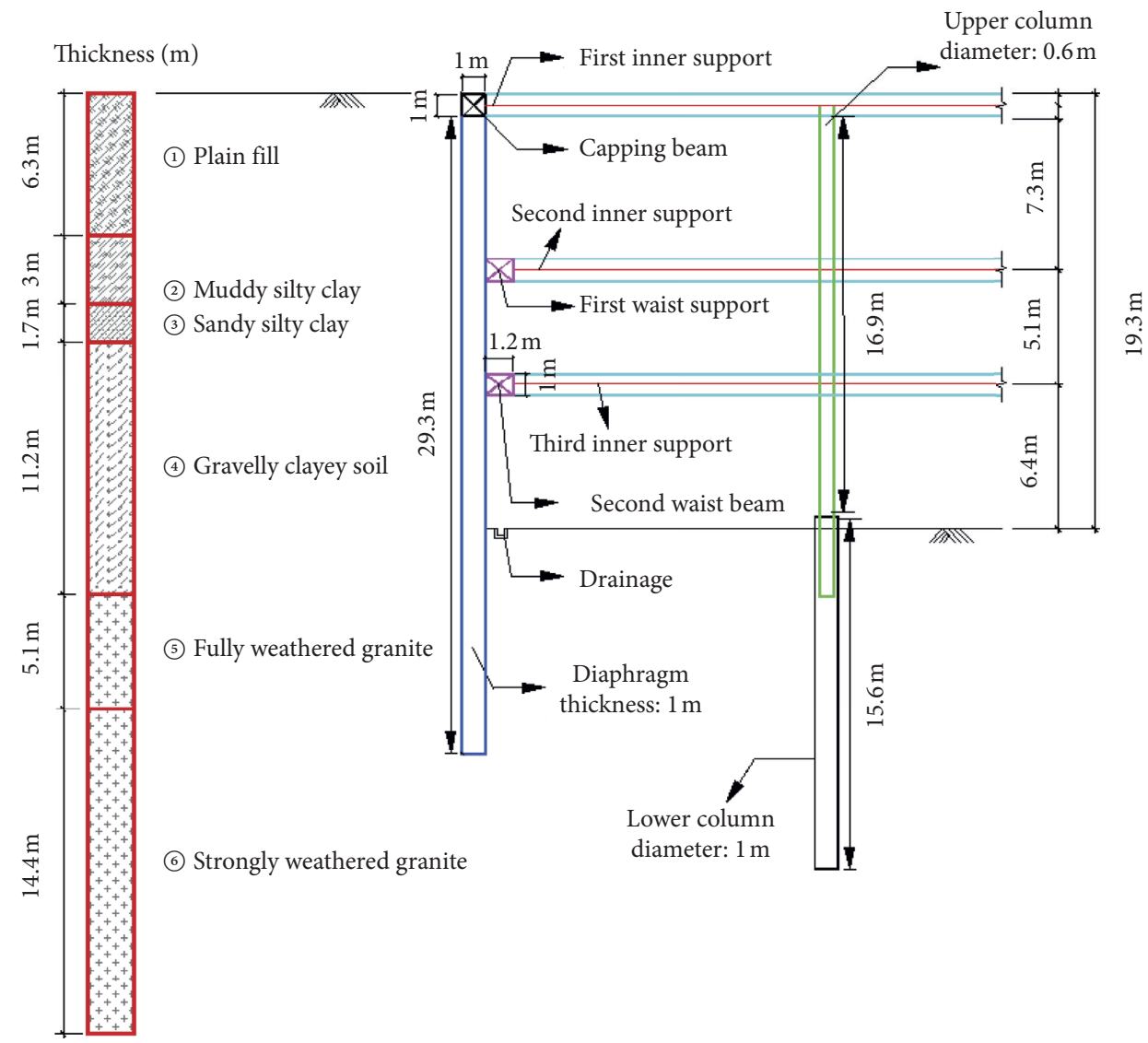

Figure 3: Cross section of $A-A$.

$$
\begin{aligned}
& E_{0}=\left(1+\frac{2 \mu^{2}}{1-\mu}\right) E_{S}, \\
& E_{S}=\frac{1+e_{0}}{a} a=\frac{e_{1}-e_{2}}{p_{2}-p_{1}}, \\
& e_{1}=e_{0}-\frac{\Delta h}{h_{0}}\left(1+e_{0}\right), \\
& \mu=\frac{K}{1+K}, \\
& e_{2}=e_{0}-\frac{\Delta h}{h_{0}}\left(1+e_{0}\right), \\
& K=1-\sin \varphi_{0} .
\end{aligned}
$$

The Earth pressure during the experiment would not exceed $50 \mathrm{kPa}$. The values of $p_{2}$ and $p_{1}$ were $25 \mathrm{kPa}$ and $50 \mathrm{kPa}$, respectively, the variable modulus of Earth pressure within $50 \mathrm{kPa}$ was obtained, which was more in line with the experimental situation. The proportions of similar materials used in the study are shown in Table 2. The physical-mechanical parameters of the prototype and model material are shown in Table 3.

According to the scale of the foundation pit and taking the excavation depth $H$ as the reference, the length, height, and width of the model were taken as $4 \mathrm{H}, 2 \mathrm{H}$, and $2 \mathrm{H}$, and the similarity coefficient as $n=30$. The size of the model box was determined as $2.5 \mathrm{~m}$ in length, $1.5 \mathrm{~m}$ in width, and $1.5 \mathrm{~m}$ in height (Figure 4). The diaphragm wall was simulated by the PPR board in the physical model. According to the similarity ratio, the thickness of the board was $33 \mathrm{~mm}$ and the length was $98 \mathrm{~cm}$. The inner support and waist beam were simulated by $33 \mathrm{~mm}$ and $40 \mathrm{~mm}$ thick steel, respectively, and the anchorage to the diaphragm wall was fixed by self-drilling nails. The column was simulated by iron rods with diameters of $3 \mathrm{~cm}$ and $2 \mathrm{~cm}$ and connected with the inner support by iron wire tying.

4.2. Data Collection. During the experiment, a joint monitoring method of stress and displacement was adopted. The stress monitoring was used for the Earth pressure cell to test the Earth pressure of the diaphragm wall under all working stages. The equipment was a 20 -channel $100 \mathrm{~Hz}$ dynamicstatic strain apparatus and the Earth pressure cell. Displacement monitoring was mainly performed to monitor the displacement of the diaphragm wall and vertical deformation of the surrounding soil in real time. The equipment adopts a dial indicator and three-dimensional (3D) deformation monitor (Figure 4). The length of the 3D deformation monitor was kept as $100 \mathrm{~cm}$, in which the displacement of one point can be monitored after every 
TABle 2: Proportions and properties of similar materials.

\begin{tabular}{|c|c|c|c|c|c|c|c|}
\hline Number & Bentonite (\%) & Sand (\%) & Density $\left(\mathrm{kg} / \mathrm{m}^{3}\right)$ & Moisture content (\%) & Cohesion $(\mathrm{kPa})$ & Friction angle $\left({ }^{\circ}\right)$ & Variable modulus (MPa) \\
\hline 1 & 38 & 62 & 1.56 & 16 & 15.58 & 20.23 & 0.36 \\
\hline 2 & 38 & 62 & 1.6 & 18 & 14.56 & 12.32 & 0.49 \\
\hline 3 & 38 & 62 & 1.64 & 20 & 10.69 & 7.77 & 0.33 \\
\hline 4 & 38 & 62 & 1.68 & 22 & 7.74 & 6.23 & 0.72 \\
\hline 5 & 34 & 66 & 1.56 & 18 & 12.06 & 16.7 & 0.70 \\
\hline 6 & 34 & 66 & 1.6 & 16 & 10.01 & 23.6 & 0.87 \\
\hline 7 & 34 & 66 & 1.64 & 22 & 6.95 & 8.53 & 0.38 \\
\hline 8 & 34 & 66 & 1.68 & 20 & 9.78 & 13.81 & 0.98 \\
\hline 9 & 30 & 70 & 1.58 & 20 & 1.365 & 23.6 & 0.87 \\
\hline 10 & 30 & 70 & 1.6 & 22 & 1.82 & 23.6 & 3.24 \\
\hline 11 & 30 & 70 & 1.64 & 16 & 7.735 & 26.17 & 1.76 \\
\hline 12 & 30 & 70 & 1.68 & 18 & 13.2 & 20.92 & 1.83 \\
\hline 13 & 26 & 74 & 1.56 & 22 & -0.6825 & 32.13 & 2.33 \\
\hline 14 & 26 & 74 & 1.6 & 20 & 12.01 & 27.42 & 1.50 \\
\hline 15 & 26 & 74 & 1.64 & 18 & 5.69 & 32.13 & 2.89 \\
\hline 16 & 26 & 74 & 1.68 & 16 & 15.93 & 30.96 & 3.44 \\
\hline 17 & 32 & 68 & 1.58 & 0.22 & 5.92 & 26.17 & 1.10 \\
\hline 18 & 30 & 70 & 1.56 & 0.22 & 1.59 & 19.54 & 1.44 \\
\hline 19 & 30 & 70 & 1.52 & 0.22 & 4.01 & 20.92 & 1.18 \\
\hline 21 & 30 & 70 & 1.55 & 0.23 & 1.592 & 19.53 & 0.54 \\
\hline 22 & 26 & 74 & 1.56 & 0.22 & 0 & 28 & 2.34 \\
\hline
\end{tabular}

TABle 3: Physical-mechanical parameters of prototype and model material.

\begin{tabular}{lccccc}
\hline Layer number & Weight $\left(\mathrm{kN} / \mathrm{m}^{3}\right)$ & Variable modulus $\left(E_{0}\right)$ & Cohesion $(\mathrm{kPa})$ & Friction angle $\left(^{\circ}\right)$ & Thickness $(\mathrm{m})$ \\
\hline Granite residual soil & 18.5 & 21 & 22 & 22 & 22.2 \\
No1 similar material & 18.9 & 0.87 & 1.36 & 23.6 & 0.74 \\
Fully weathered granite & 20 & 80 & 20 & 25 & 10.2 \\
No2 similar material & 19 & 2.3 & 0 & 28 & 0.3 \\
\hline
\end{tabular}

$25 \mathrm{~cm}$. In this experiment, two 3D deformation monitors were installed staggered on the diaphragm wall. The diaphragm wall was $98 \mathrm{~cm}$ long, so that the displacement of the wall was monitored after every $12.5 \mathrm{~cm}$ and the displacement data of 8 points were monitored at the same time. The above sensors were arranged in the center of the diaphragm wall. In Figure 5, “ $A$ " represents the position sensor, " $B$ ” represents the monitoring point of the Earth pressure cell, and " $H$ " represents the length of the diaphragm wall. The layout of each sensor is shown in Figure 6.

\subsection{Experimental Procedure}

4.3.1. Model Installation. The first step in the experimental procedure was to install the displacement sensors and Earth pressure cell. One Earth pressure cell was arranged on the lower side of each row of waist beams, and three Earth pressure cells were densely arranged in the embedded section of the diaphragm wall. The second step was to embed the diaphragm wall and the columns. The third step was to install the dial indicator on the surface of the soil behind the diaphragm wall after the soil compaction was completed, which was used to determine the vertical deformation of the soil settlement during the excavation of the foundation pit.

4.3.2. Physical Experiment Stages. The excavation process of the foundation pit was completely in accordance with the actual foundation pit excavation.

Stage 1: the excavation face was taken as zero-point, excavated $4 \mathrm{~cm}$, and installed within the first row of inner support at the top of the diaphragm wall

Stage 2: excavated $24.3 \mathrm{~cm}$ on the basis of stage 1, excavated to $28 \mathrm{~cm}$, and installed the second row of inner support

Stage 3: excavated $17 \mathrm{~cm}$ on the basis of stage 2, excavated to $45 \mathrm{~cm}$, and installed the third row of inner supports

Stage 4: excavated $21.3 \mathrm{~cm}$ on the basis of stage 3 , and excavated to $64 \mathrm{~cm}$ as shown in Figure 7

In the aforementioned excavation physical process, the soil settlement, Earth pressure and diaphragm displacement were recorded in real time. So far, the whole process of the physical excavation experiments for the embedded length of 


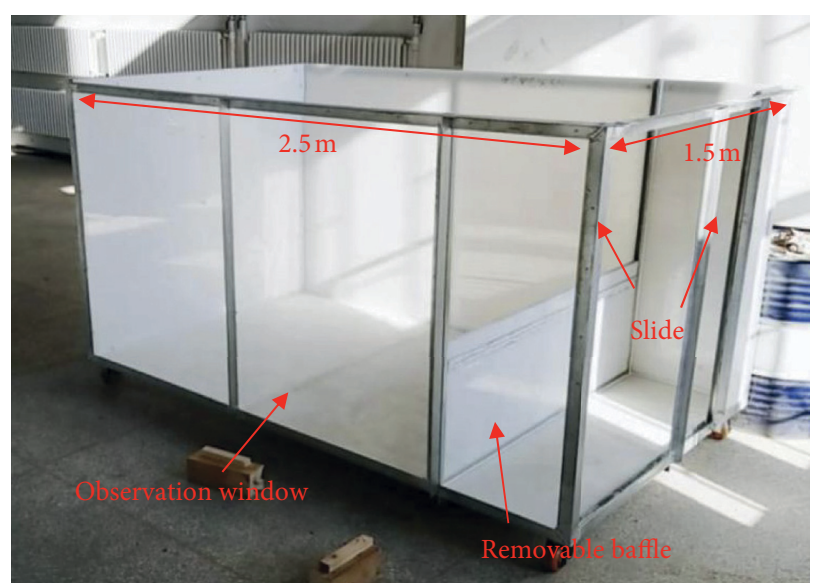

(a)

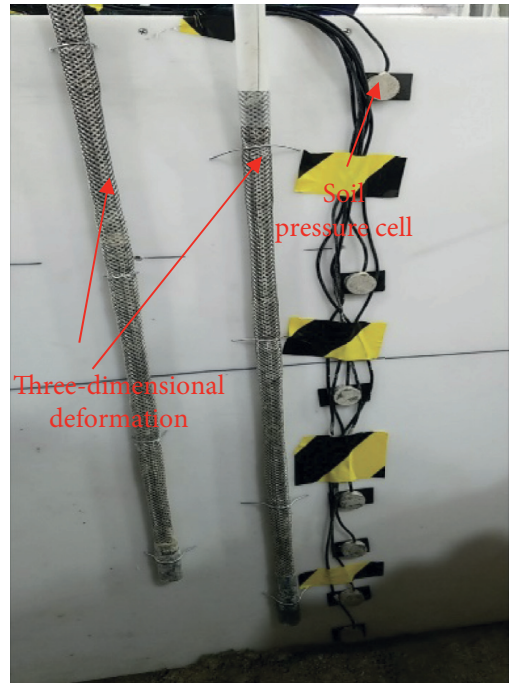

(c)

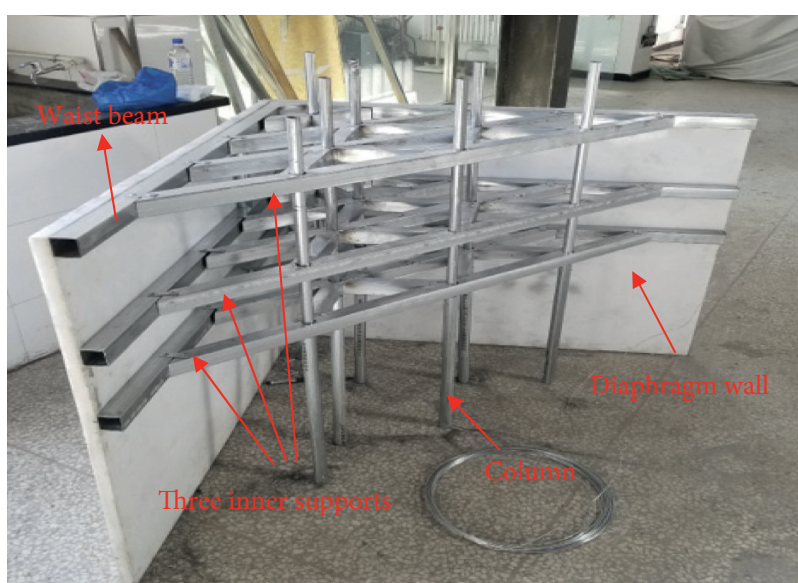

(b)

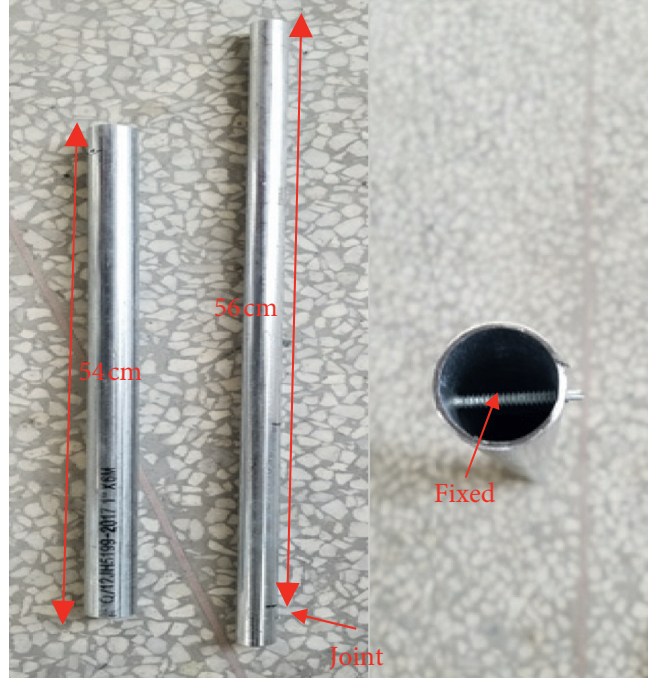

(d)

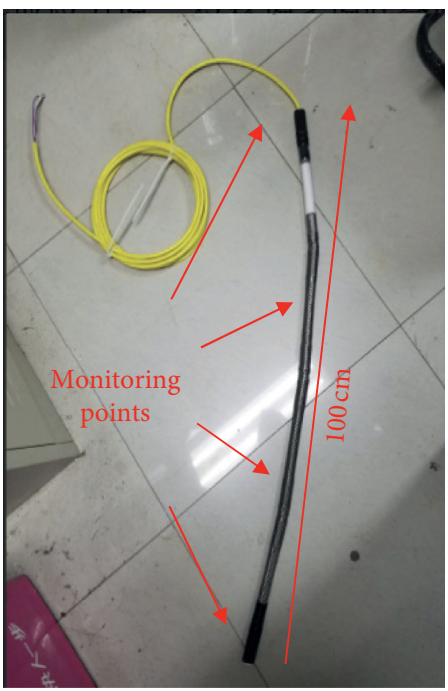

(e)

Figure 4: The preparatory work. (a) Model box. (b) Supporting structure. (c) Monitoring equipment. (d) Diagram of the column. (e) Displacement monitor. 


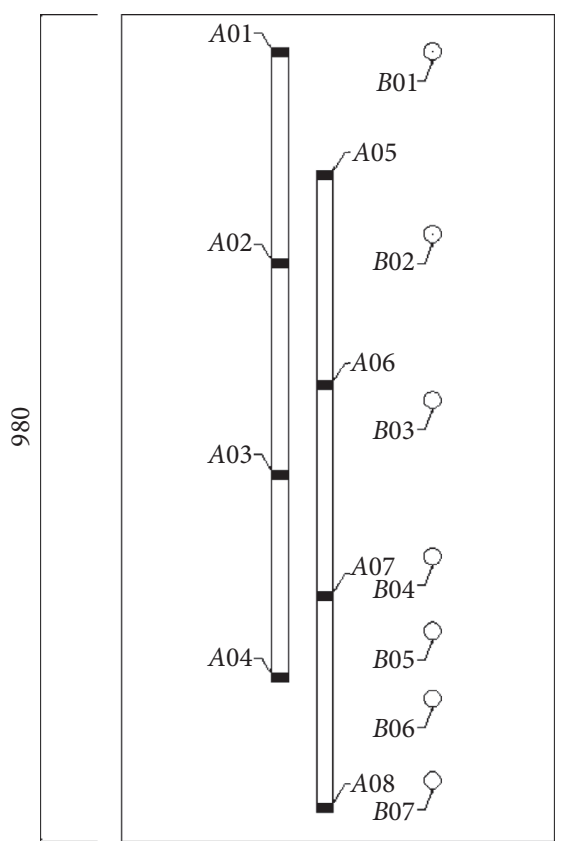

(a)

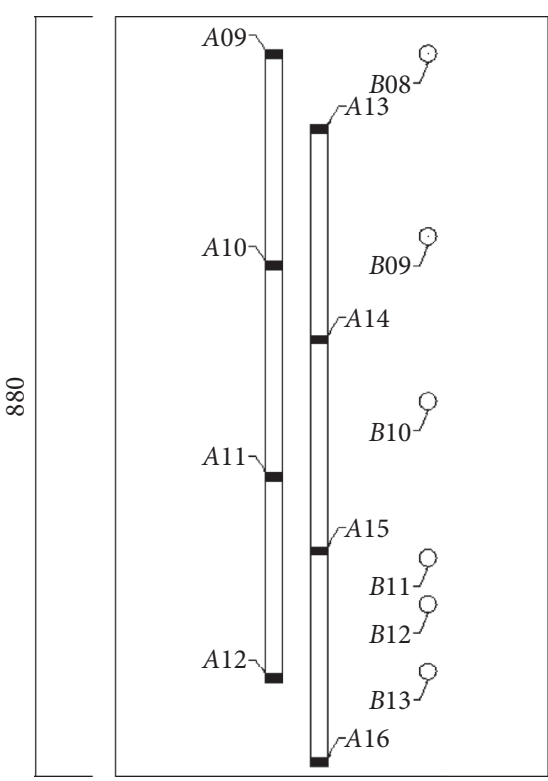

(b)

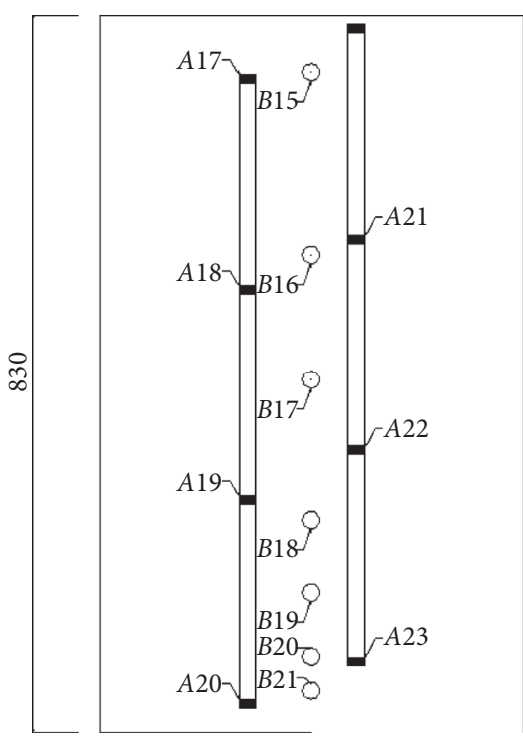

(c)

Figure 5: The location of the displacement sensor and Earth pressure cell. (a) The embedded depth of $0.40 \mathrm{H}$. (b) The embedded depth of $0.36 \mathrm{H}$. (c) The embedded depth of $0.30 \mathrm{H}$.

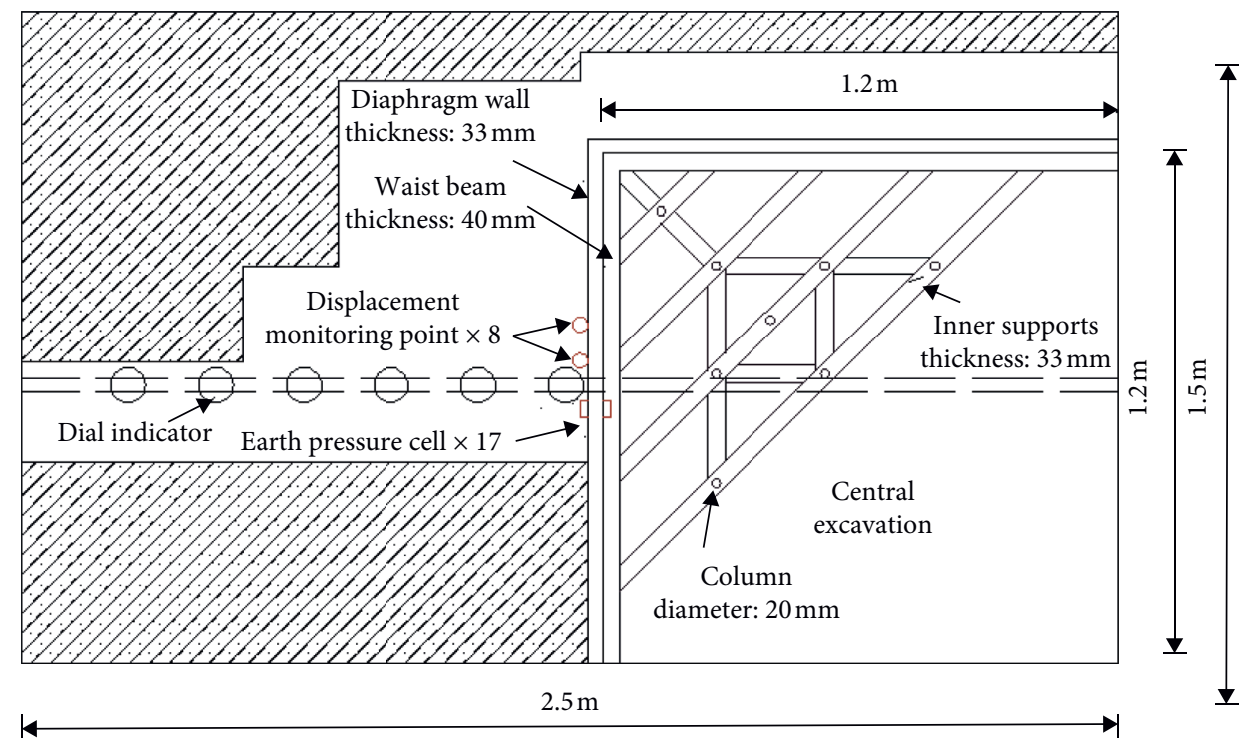

Figure 6: Overlooking map.

a diaphragm wall was completed. The embedded length was then changed and repeated the above steps under the stages of $L / H=0.36(24 \mathrm{~cm})$ and $L / H=0.3(19 \mathrm{~cm})$ to obtain the distribution laws of displacement and Earth pressure under different diaphragm wall embedded depths.

\section{Numerical Simulation}

5.1. Model Parameter Selection. The study took a quarter of the foundation pit for 3D modeling calculation analysis same as the physical model experiment. Considering the influence of wall displacement and ding to the analysis results of horizontal displacement and settlement, the settlement, the height of the modeled foundation pit was taken as the influence range of the surrounding soil at twice the excavation depth $(H=19.3 \mathrm{~m})$. The overall size was $78.8 \mathrm{~m}$ (length) $\times$ $72.8 \mathrm{~m}$ (width) $\times 40 \mathrm{~m}$ (height), as shown in Figure 8 .

The modified Coulomb constitutive model was adopted for soil mass. The traditional Mohr-Coulomb model was an elastoplastic model, which could not consider the influence of soil unloading modulus changes. The final simulated value had a great difference from the 


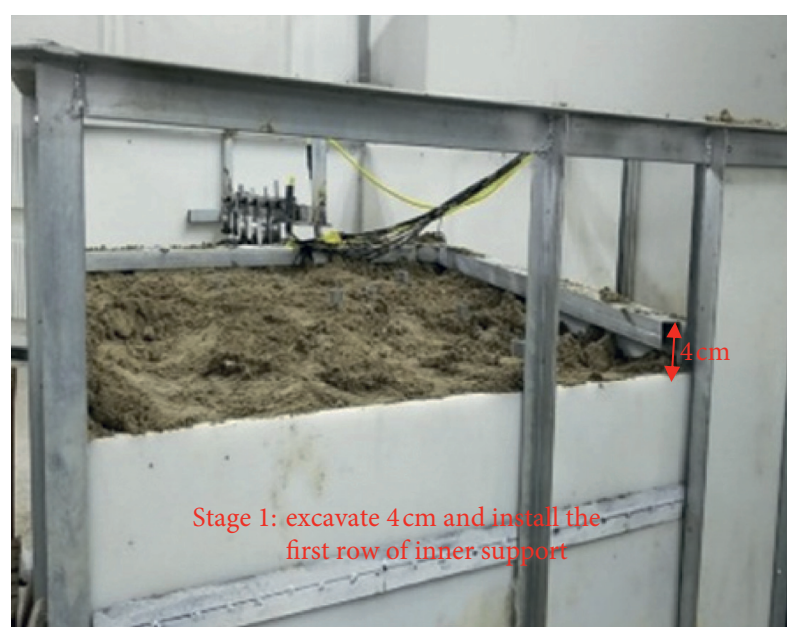

(a)

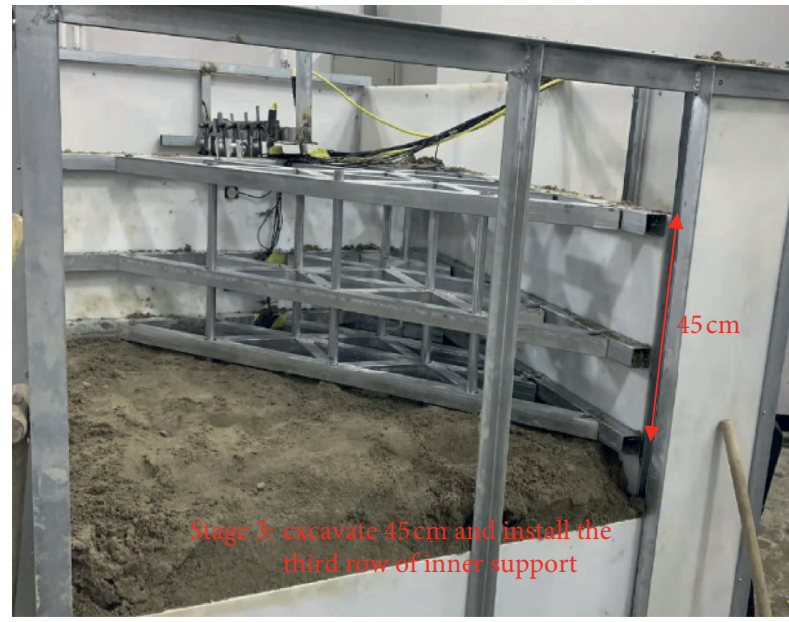

(c)

Figure 7: Excavation stage of foundation pit.

actual monitoring data. The modified Mohr-Coulomb constitutive model could be regarded as an improved version of the former. The latter had the same shear yield surface as the former, but it used rounded corners to make the model more convergent. The compression yield surface was elliptical, and its shear yield surface and compression yield surface did not affect each other. The model could consider the change of elastic modulus of soil with the change of stress, so it was more practical than the Mohr-Coulomb model. The soil parameters of the model and the supporting structure parameters are shown in Table 4 and 5, respectively.

According to the excavation and support process of the foundation pit, the simulation calculation process was divided into the following 4 stages:

Preparation stage: it consists of the generation of the initial stress field, activation of all soil layers, activation of deadweight and boundary displacement constraint conditions, reset of the displacement, and the derivation of diaphragm wall and column

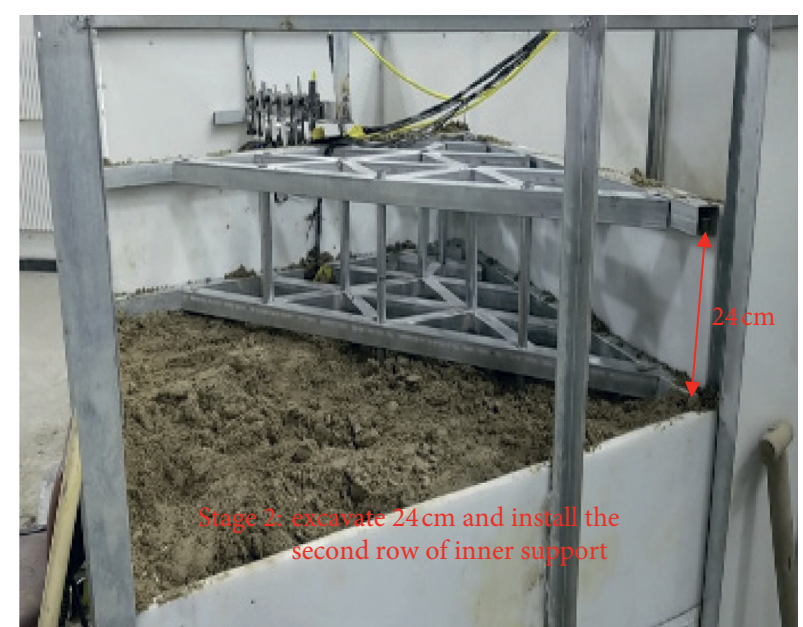

(b)

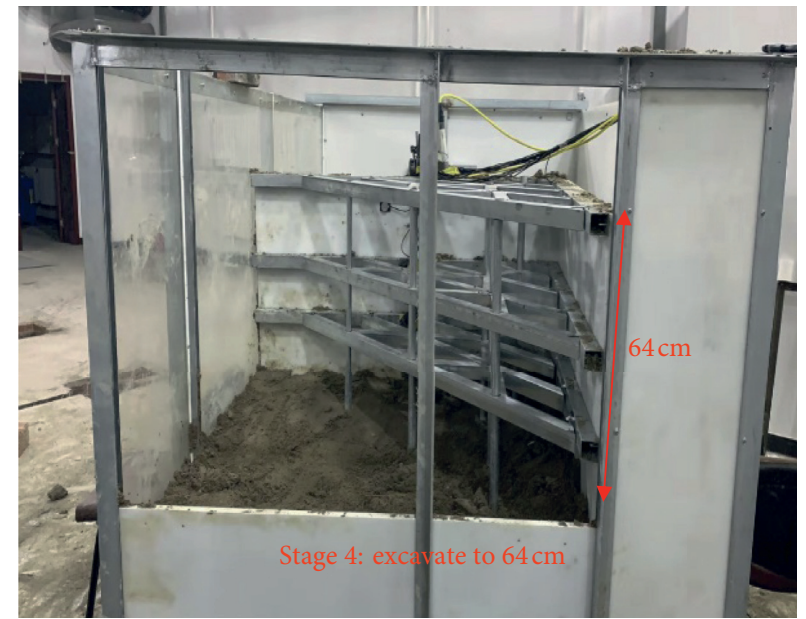

(d)

(a) Stage 1. (b) Stage 2. (c) Stage 3. (d) Stage 4.

Stage 1: the excavation surface was taken as the starting point, excavated $1 \mathrm{~m}$, and overexcavated $0.5 \mathrm{~m}$

Stage 2: the first layer was set as the inner support and waist beam at the site of $-0.5 \mathrm{~m}$, excavated $7.3 \mathrm{~m}$ on the basis of stage 1 , and overexcavated $0.5 \mathrm{~m}$

Stage 3: the second layer was set as the inner support and waist beam, excavated $5.1 \mathrm{~m}$ on the basis of stage 2 , and overexcavated $0.5 \mathrm{~m}$

Stage 4: the third layer was set as the inner support and waist beam and excavated $5.9 \mathrm{~m}$ on the basis of stage 3

\section{Results and Discussion}

6.1. Comparison between the Physical Modeling and Numerical Simulations. The results of the physical experiments were expanded 30 times in proportion, and compared with the results of the numerical simulation, the comparison diagram of wall displacement, soil settlement, and Earth pressure were obtained successively. Among 


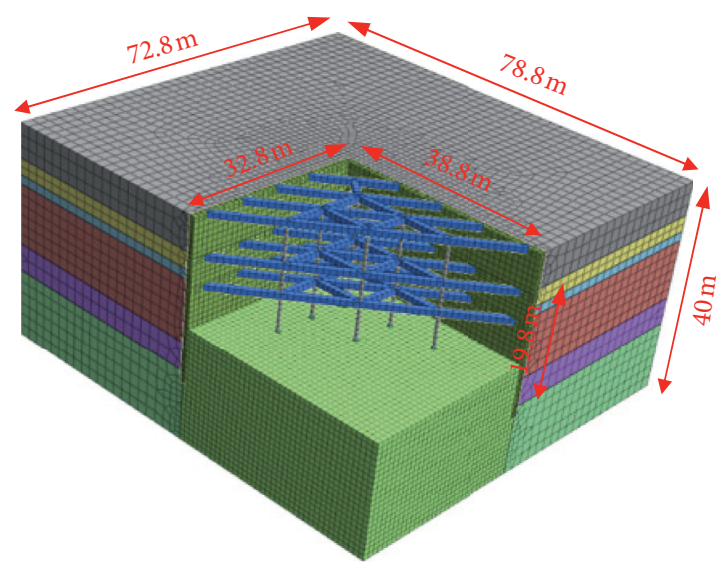

(a)

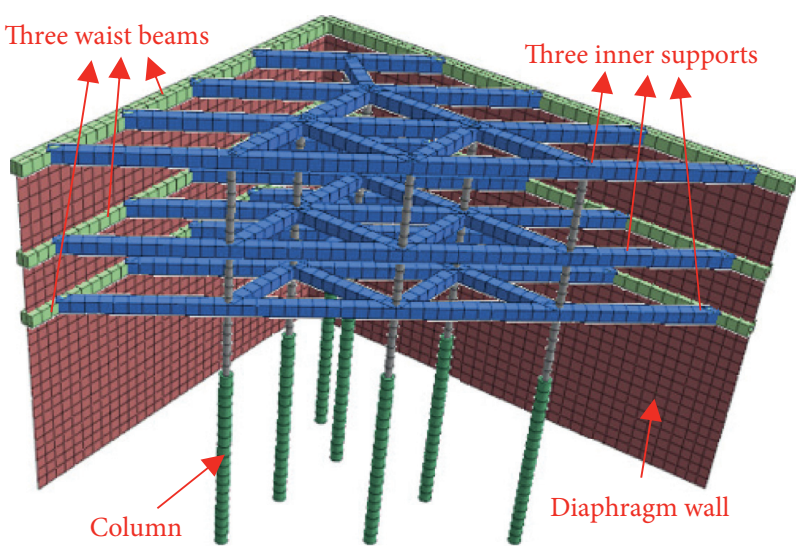

(b)

Figure 8: FEM mesh of the calculation model. (a) Foundation pit grid. (b) Supporting structure grid.

TABLE 4: Geotechnical parameters used in the study.

\begin{tabular}{lccccccccccccc}
\hline Parameter & SPT-blow count $/ N$ & $\alpha$ & $E_{5 D}^{\text {ref }} / \mathrm{MPa}$ & $E_{\text {oed }}^{\text {ref }} / \mathrm{MPa}$ & $E_{\mathrm{ur}}^{\mathrm{ref}} / \mathrm{MPa}$ & $\mathrm{C} / \mathrm{kPa}$ & $\Phi /^{\circ}$ & $\sigma^{\mathrm{ref}} / \mathrm{kPa}$ & $n$ & $R_{\mathrm{f}}$ & $K_{0}$ & $m$ & $\Psi /^{\circ}$ \\
\hline Plain fill & 6.1 & 13 & 8.19 & 8.19 & 49.1 & 15 & 15 & 100 & 0.44 & 0.9 & 0.74 & 0.7 & 0 \\
Muddy silty clay & 2.6 & 1.3 & 6.2 & 6.2 & 37.2 & 15 & 3 & 100 & 0.52 & 0.9 & 0.94 & 0.7 & 0 \\
Sandy silty clay & 11.6 & 1.3 & 23.2 & 23.2 & 139.2 & 25 & 20 & 100 & 0.41 & 0.9 & 0.66 & 0.7 & 0 \\
Gravel clay & 21.2 & 1.3 & 20 & 20 & 120 & 22 & 22 & 100 & 0.44 & 0.9 & 0.62 & 0.7 & 0 \\
Fully weathered granite & 36.5 & 2.0 & 80 & 80 & 480 & 20 & 25 & 100 & 0.49 & 0.9 & 0.58 & 1 & 0 \\
Strongly weathered granite & 63.4 & 2.0 & 120 & 120 & 720 & 18 & 30 & 100 & 0.45 & 0.9 & 0.5 & 1 & 5 \\
\hline
\end{tabular}

TABle 5: Support structure parameters.

\begin{tabular}{lccccc}
\hline Parameter & Inner support & Waist beam & Lower column & Upper column & Diaphragm wall \\
\hline Section $/ \mathrm{m}$ & $1 \times 1$ & $1 \times 1$ & $R=0.6$ & $R=1$ & $D=1$ \\
Materials & C30 & C30 & HRB235 & HRB235 & C30 \\
\hline
\end{tabular}

them, $M-1$ represented the physical experiment stage 1 , $N-2$ represented the numerical simulation stage 2 , and so on.

The trends of numerical simulation and physical experiments are basically the same as depicted in Figure 9. In stage 1 , stage 2 , and stage 3 , the inner supports were installed after excavation, and the wall displacement did not significantly change. Stage 4 had a large excavation depth and no new inner support was installed, resulting in the largest change in the wall displacement. The maximum deformation values of the wall were very close to $11.3 \mathrm{~mm}$ and $15.9 \mathrm{~mm}$. The minimum displacement of the wall appeared below the excavation surface of the foundation pit, indicating that the soil had a restraint effect on the wall and the embedded effect was obvious at the excavation surface. Both the physical experiments and the numerical simulation of the wall displacement curve were "big bellyshaped," and the maximum horizontal displacement position $d_{h m}$ was located at the ratios of $0.33 \mathrm{H}$ and $0.57 \mathrm{H}$, respectively. The average value of the maximum horizontal displacement position of the granite residual soil foundation pit in Shenzhen is $0.56 \mathrm{H}$ [6], which was very close to the experimental results.
The physical experiments and numerical simulation of the soil settlement are shown in Figure 10, both of which are "groove-shaped," with the maximum settlement values of $7.7 \mathrm{~mm}$ and $6.6 \mathrm{~mm}$, respectively, and the maximum values appeared at $0.15 \mathrm{H}$ and $0.40 \mathrm{H}$ from the pit edge. From the abscissa at $22 \mathrm{~m}$ in Figure 10, it could be found that the settlement value of the numerical simulation was larger at the edge of the pit. This was caused by a certain time effect in the physical experiment process, but it did not affect the deformation law of the settlement curve.

It can be seen from Figures 11 and 12 that the Earth pressure of the physical experiments is greater than the numerical simulation. As the physical experiment soil sample was reshaped, it caused undergoing a series of steps as drying, stirring, and compaction during the experiments. Then, the structure of the undisturbed soil had been lost, resulting in a certain difference between the results of physical experiments and numerical simulations. In general, it can be seen from Figures 9-12 that the results and changing trends of the physical model experiments and the numerical simulation are basically the same, which can represent the accuracy of the physical model experiments. 


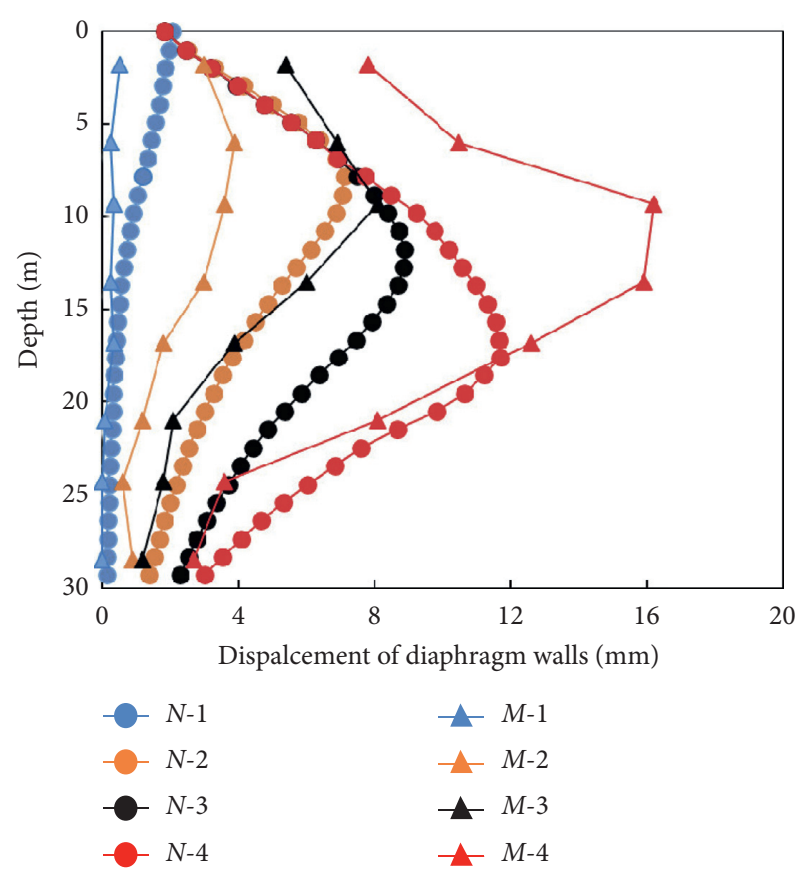

Figure 9: Diaphragm wall displacement of $0.4 \mathrm{H}$.

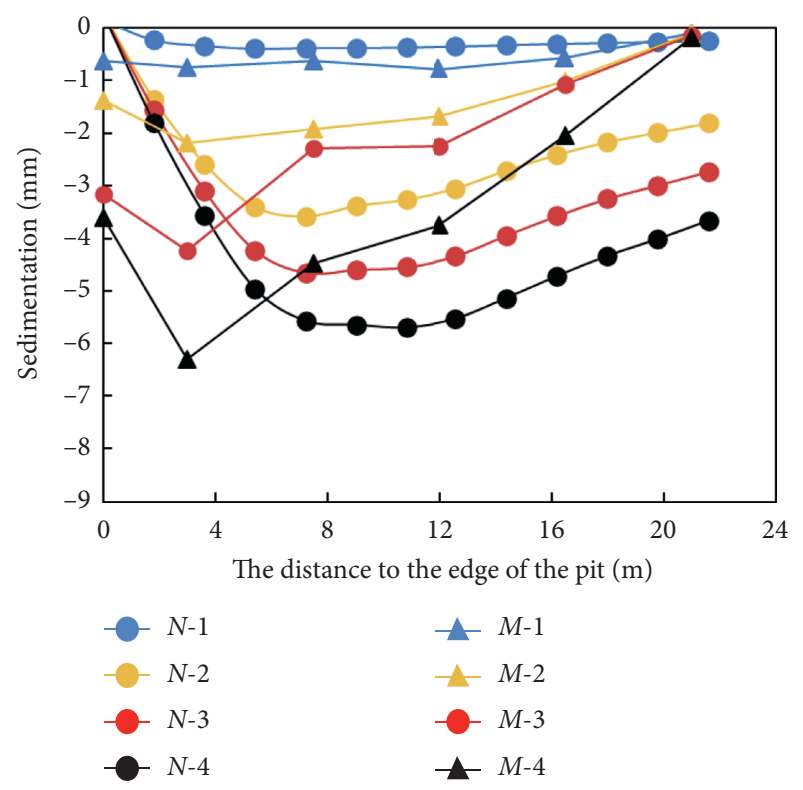

Figure 10: Soil settlement Contras of $0.40 \mathrm{H}$.

6.2. Comparison between Physical Experiment and Monitoring Results. A comprehensive dynamic monitoring of the foundation pit supporting structure and the surrounding environment was carried out during the construction of the foundation pit, including the lateral displacement $(X C)$ of the diaphragm wall and the soil settlement $(W)$ behind the wall as shown in Figure 2. The layout of the measuring points is also shown in Figure 2. The results of the physical experiments were enlarged by 30 times and compared with the monitoring results. The results of the settlement and displacement are very close as shown in Figure 13. The two monitoring points of $\mathrm{XC1}$

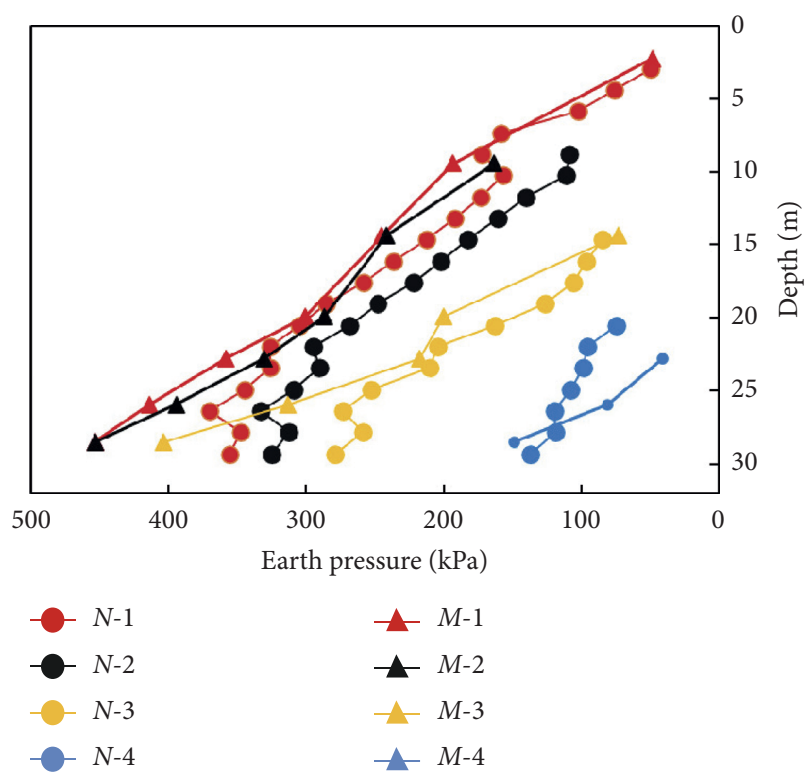

Figure 11: Earth pressure in front of the wall of $0.4 \mathrm{H}$.

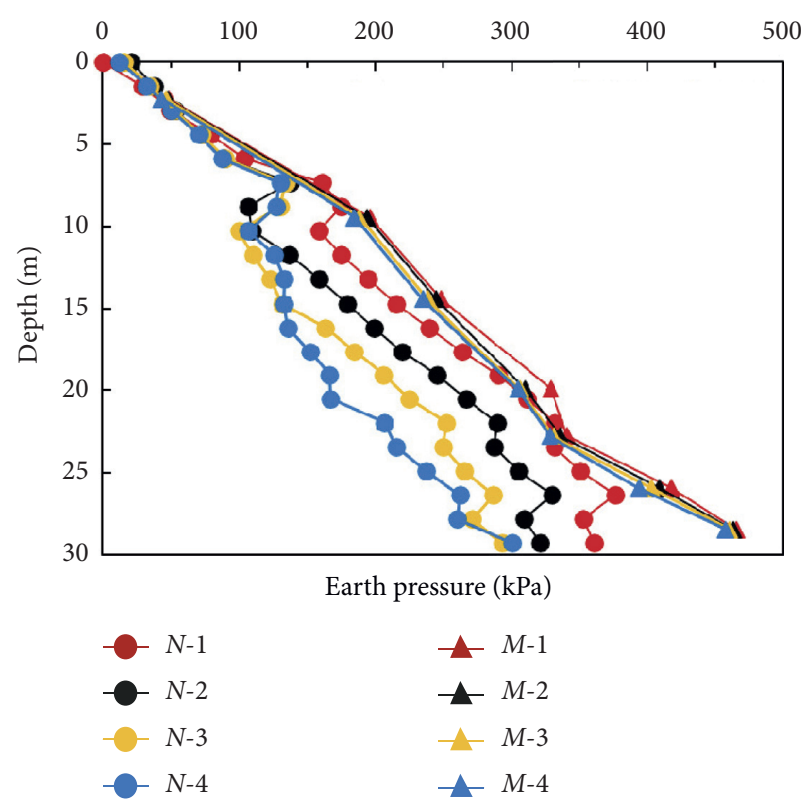

FIgURE 12: Earth pressure behind the wall of $0.4 \mathrm{H}$.

and $W 2$ were $10.2 \mathrm{~mm}$ and $7.4 \mathrm{~mm}$, and the difference from the physical experiment result was $2.3 \mathrm{~mm}$ and $1.6 \mathrm{~mm}$, respectively (accounting for $22.5 \%$ and $21.6 \%$ of the actual measured value, respectively). The difference between the monitoring and the experiment results is not very large, which shows the accuracy of the physical model experiment.

6.3. Minimum Embedded Depth. The wall displacement, soil settlement, and Earth pressure were obtained through the excavation physical experiments of foundation pit with different embedded depths of diaphragm walls $(L / H=0.36$, $L / H=0.3$ ). 


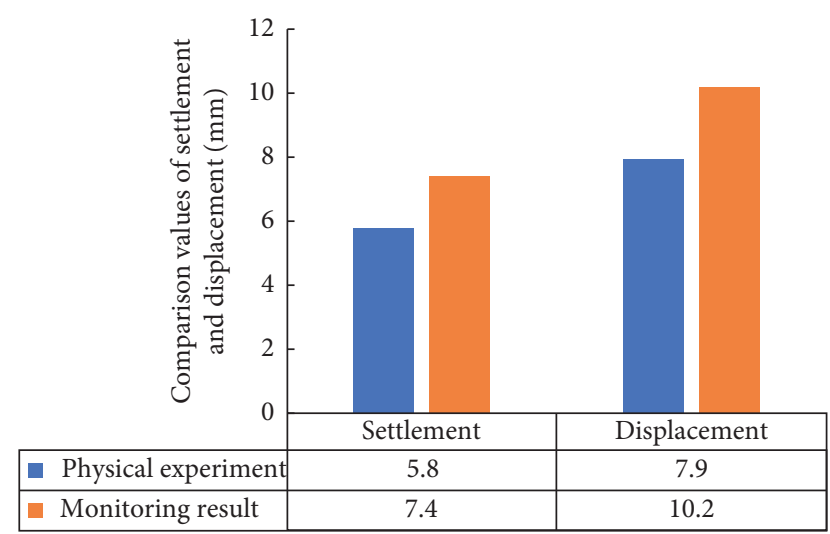

Figure 13: Comparison between the results of settlement and displacement.

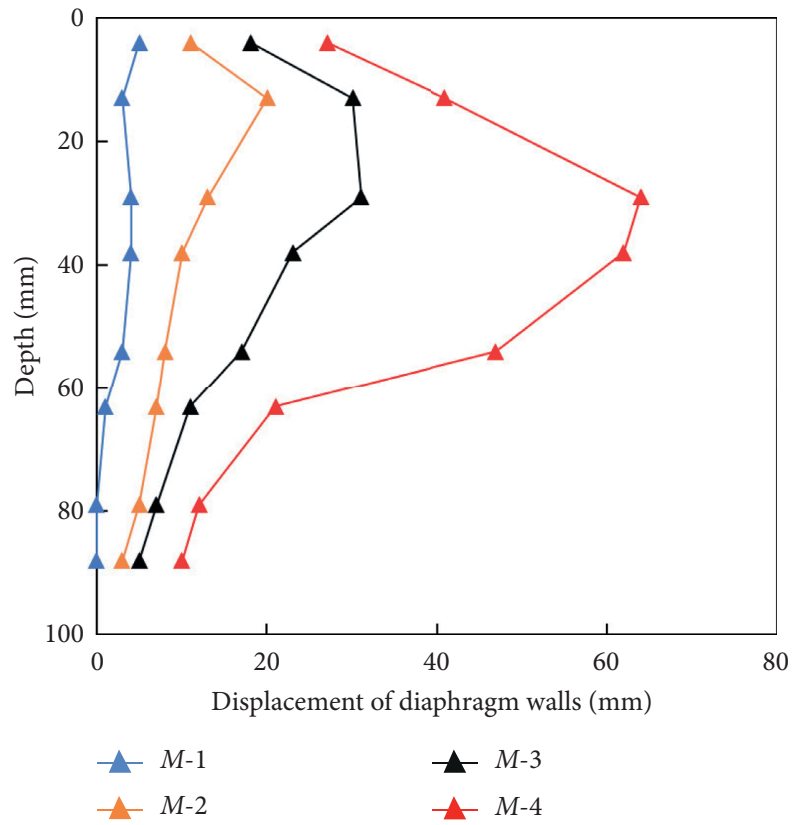

Figure 14: Wall displacement of $0.36 \mathrm{H}$.

6.3.1. Wall Horizontal Displacement. It can be seen in Figures 14 and 15 that the lateral displacement of the diaphragm wall is as "large belly". The horizontal displacement of the diaphragm wall increases continuously with the increase of excavation depth; especially after stage 4 , the increase of displacement is particularly obvious. The smaller the embedded depth is, the greater the final horizontal displacement of the wall with the change in embedded depth is. The maximum wall displacement value reaches $0.14 \% \mathrm{H}$, which is very close to the average value of the maximum horizontal displacement of the foundation pit wall in the granite residual soil area, as $0.13 \% \mathrm{H}$ [6]. It was found from experiments that the displacement at the top of the wall is generally small, which shows that the crown beam plays a significant role.

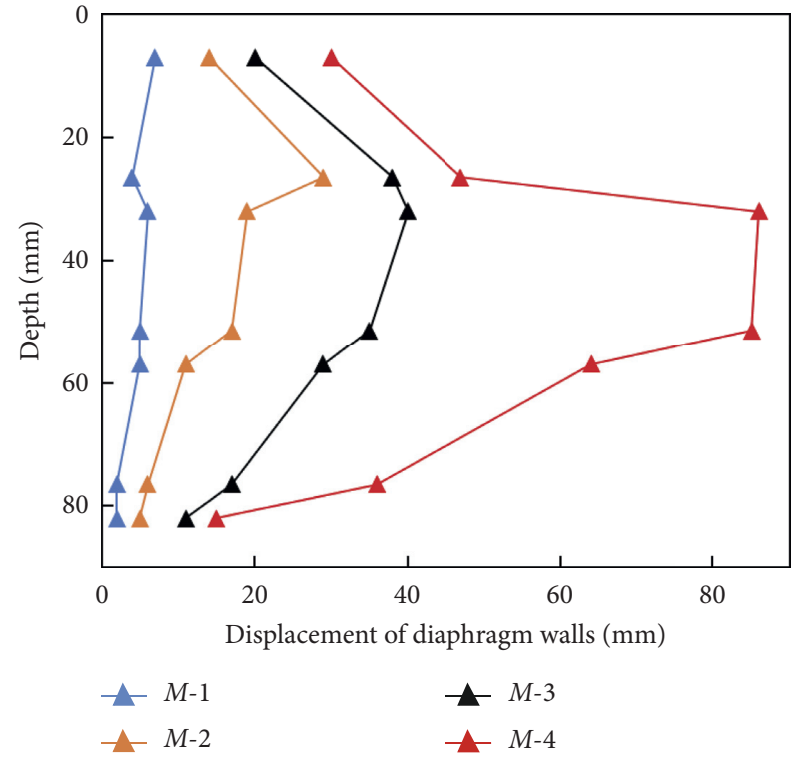

Figure 15: Wall displacement of $0.30 \mathrm{H}$.

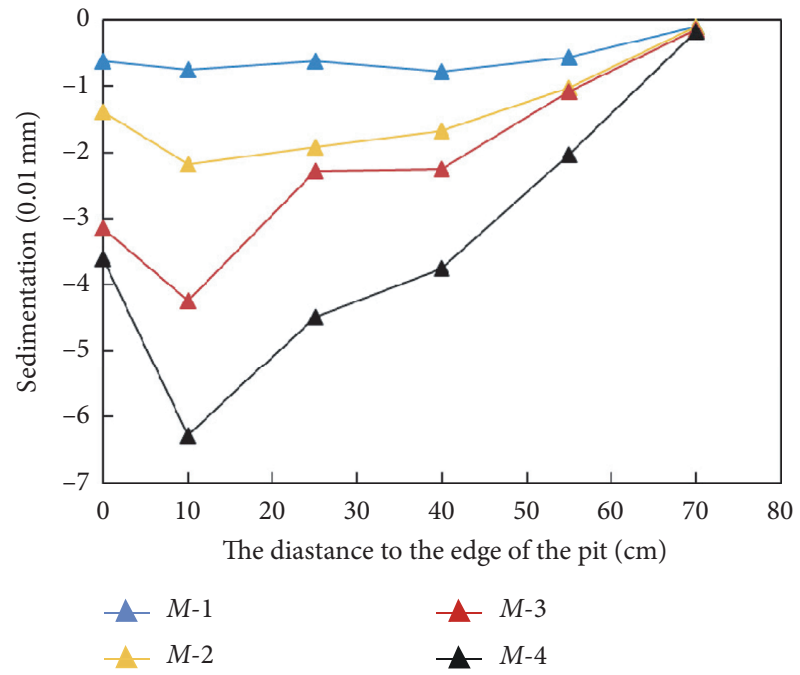

FIgURE 16: Soil settlement of $0.36 \mathrm{H}$.

6.3.2. Soil Settlement Behind the Walls. It can be seen in Figures 16 and 17 that with the increase in distance from the diaphragm wall, the soil settlement will first increase and then decrease significantly, forming a groove-shape. The maximum soil settlement appears at about $0.23 \mathrm{H}$ from the pit. The maximum soil settlement gradually increases with the continuous decrease in embedded depth, and the maximum settlement value under the two embedded depths was $0.25 \mathrm{~mm}, \delta_{v m} / H=0.04 \%$, and $0.45 \mathrm{~mm}, \delta_{v m} / H=0.07 \%$, respectively. The influence range of the settlement was also expanded significantly with the decrease in embedded depth, and hence the influence range of the last settlement exceeded the monitoring range of $70 \mathrm{~cm}$. 


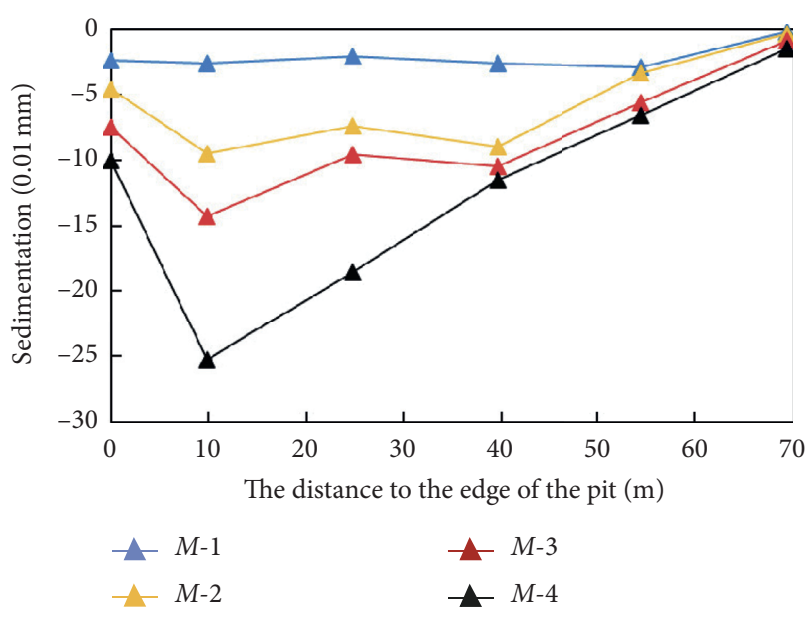

Figure 17: Soil settlement of $0.30 \mathrm{H}$.

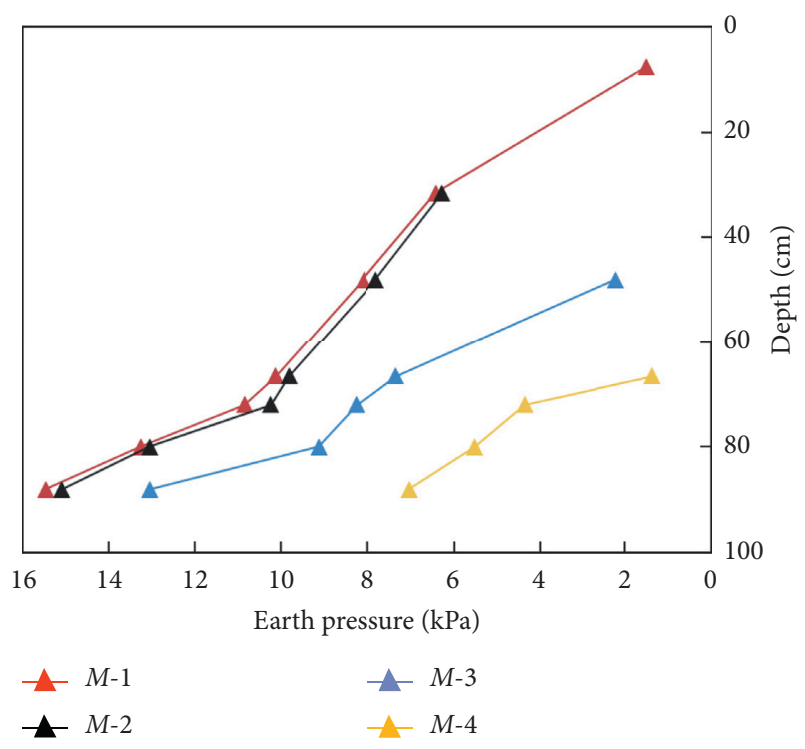

Figure 18: Earth pressure in front of the wall of $0.36 \mathrm{H}$.

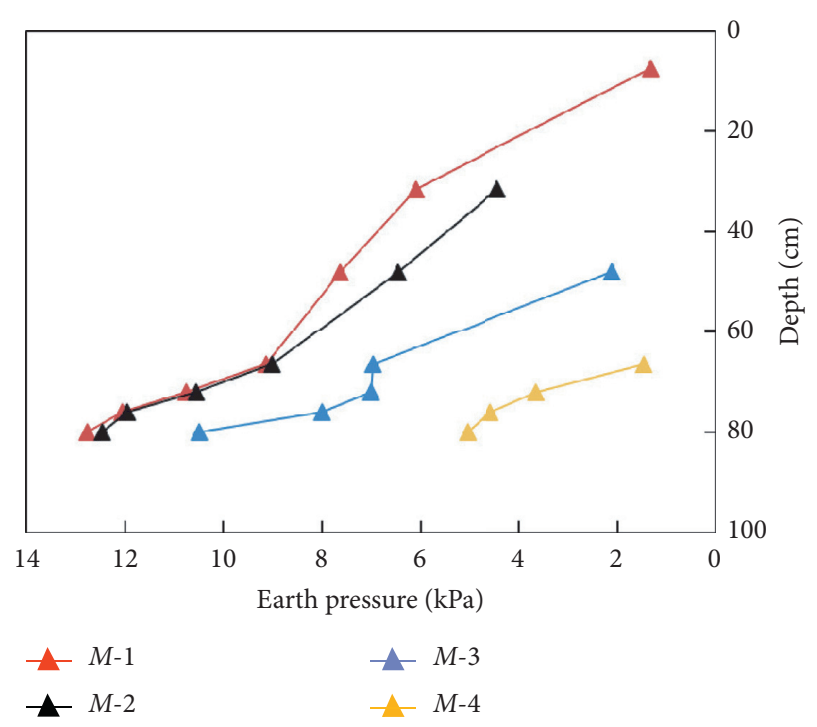

Figure 19: Earth pressure in front of the wall of $0.30 \mathrm{H}$.
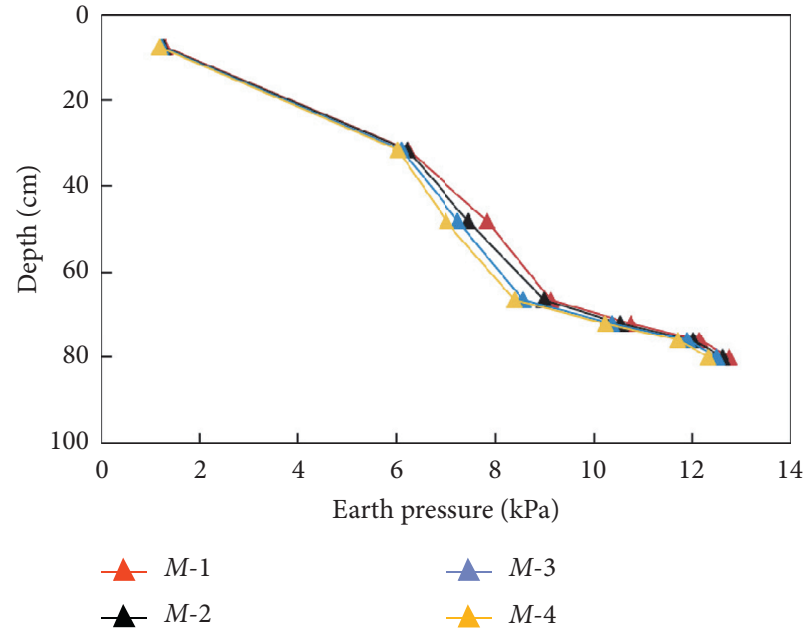

Figure 20: Earth pressure behind the wall of $0.36 \mathrm{H}$.

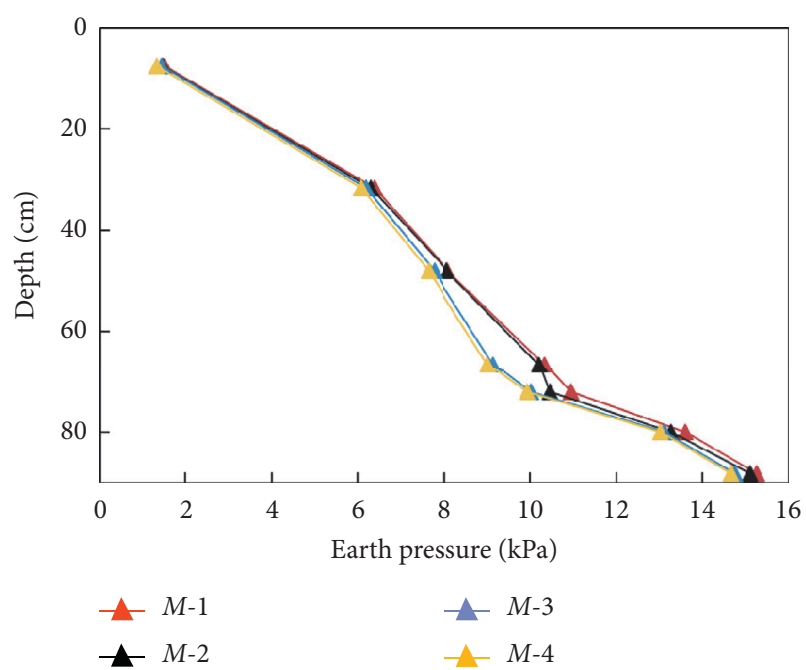

Figure 21: Earth pressure behind the wall of $0.3 \mathrm{H}$.

6.3.3. Earth Pressure. The interior of the foundation pit belongs to the passive Earth pressure area, while the exterior of the foundation pit belongs to the active Earth pressure area according to the displacement law of the diaphragm wall. The Earth pressure in front of the wall decreased continuously with the increasing depth of excavation. The excavation depth is shallow, so the Earth pressure does not change significantly during the first stage; when the excavation depth was deepened, the Earth pressure significantly changed. The deformation of the wall to the interior of the foundation pit gradually increased with the increase in excavation depth, resulting in a decrease in the Earth pressure behind the wall (Figures 18-21).

\section{Conclusions}

(1) The lateral displacement of the wall during the whole process of foundation pit excavation shows the "big belly" shape: the middle part of the wall has the largest displacement, while the lower and upper 
parts have small displacement. The horizontal displacement of the wall increased, and the position of the maximum displacement value moves down with the increase of the excavation depth. By decreasing the embedded depth, the greater final horizontal displacement of the wall occurred with the maximum value of $0.9 \mathrm{~mm}, 0.14 \mathrm{H} \%$.

(2) The soil settlement behind the diaphragm wall was gradually increased with the progress of the excavation. The maximum settlement position appears approximately $0.23 \mathrm{H}$, with a maximum value of $0.45 \mathrm{~mm}, \delta_{v m} / H=0.07 \%$. The final settlement increased significantly with the decrease in embedded depth, and the influence range of settlement also increased significantly, but it did not change the groove-shaped rule of soil settlement.

(3) The passive Earth pressure in front of the wall increases linearly with the depth. The passive Earth pressure in the bottom soil of the pit decreases with the increase of the excavation depth. The excavation depth of stage 1 is relatively shallow, and the decrease of the Earth pressure is not obvious. The Earth pressure decreased obviously with the increase in excavation depth under the latest stages, because the displacement of the wall was very small during the experiment, the Earth pressure in front of and behind the wall is distributed in a triangle, which was more in line with the distribution law of the static Earth pressure.

(4) According to the analysis results of horizontal displacement and settlement, the wall displacement reached the critical value of $30 \mathrm{~mm}$ in the "Technical Code for retaining and protection of excavation in Shenzhen city" at the embedded depth of $0.36 \mathrm{H} \mathrm{[14].}$ Therefore, it is recommended that the embedded depth should not be less than $24 \mathrm{~cm}(0.36 \mathrm{H})$ for the diaphragm wall with inner supports structure.

\section{Data Availability}

The data used to support the findings of this study are included within the article.

\section{Conflicts of Interest}

The authors declare that they have no conflicts of interest.

\section{Acknowledgments}

This research was funded by the National Natural Science Foundation of China (nos. 41572257 and 41972267).

\section{References}

[1] C. Xu and X.-L. Hu, "Development and application of similar material for reservoir landslide model test," Rock and Soil Mechanics, vol. 39, no. 11, pp. 4287-4293, 2018, in Chinese.

[2] W.-G. Fu and Z.-Y. Yang, "Summaries of excavation pit engineering in Shenzhen in recent 30 years," Chinese Journal of Geotechnical Engineering, vol. 3, no. 2, pp. 562-565, 2010, in Chinese.

[3] Y.-Z. Jiang and Z.-Y. Yang, "Summary of the development of foundation pit engineering in shenzhen area," Engineering and Technological Research, vol. 4, no. 16, pp. 210-211, 2019, in Chinese.

[4] Q.-L. Cui, H.-N. Wu, S.-L. Shen, and Y.-S. Xu, "Geological difficulties and countermeasures for socket diaphragm walls in weathered granite in Shenzhen, China," Bulletin of Engineering Geology and the Environment, vol. 75, no. 1, pp. 263-273, 2016.

[5] Z. Li,, S.-G. Liu, W.-T. Ren et al., "Multiscale laboratory study and numerical analysis of water-weakening effect on shale," Advances in Materials Science and Engineering, vol. 2020, Article ID 5263431, 14 pages, 2020.

[6] F.-M. Wang and L.-L. Liu, "Deformation characteristics of supporting structure of deep foundation excavation in granite residual soil area," Construction Technology, vol. 48, no. 4, pp. 98-102, 2019, in Chinese.

[7] E.-B. Bai, Study on the Influence of High Pressure Rotary Jet Grouting Secant Pile Bottom Reinforcement on Granitic Layer on Pit Deformation, Scientific Dissertation of Guangzhou University, Guangzhou, China, 2013, in Chinese.

[8] H.-P. Wang and S.-C. Li, "Development of a new geo-mechanical similar material," Chinese Journal of Rock Mechanics and Engineering, vol. 25, no. 9, pp. 1842-1847, 2006, in Chinese.

[9] P.-F. Jiao, X. Zhang, and X.-Z. Li, "Experimental study on the ratio of similar materials in weak surrounding rock based on orthogonal design," Journal of Engineering, vol. 2018, Article ID 2591758, 6 pages, 2018.

[10] Z. Li, H. Zhou, D.-W. Hu, and C.-Q. Zhang, "Yield criterion for rocklike geomaterials based on strain energy and CMP model," International Journal of Geomechanics, vol. 20, no. 3, Article ID 04020013, 2020.

[11] Z. Li, H.-X. Liu, Z.-L. Dun, L.-W. Ren, and J.-J. Fang, "Grouting effect on rock fracture using shear and seepage assessment," Construction and Building Materials, vol. 242, pp. 118-131, 2020.

[12] Q.-X. Meng, H.-L. Wang, M. Cai, W.-Y. Xu, X.-Y. Zhuang, and T. Rabczuk, "Three-dimensional mesoscale computational modeling of soil-rock mixtures with concave particles," Engineering Geology, vol. 277, Article ID 105802, 2020.

[13] X.-D. Zhang, Y.-j. Wu, E.-C. Zhai, and P. Ye, "Coupling analysis of the heat-water dynamics and frozen depth in a seasonally frozen zone," Journal of Hydrology, vol. 1, pp. 1-53, Article ID 125603, 2020.

[14] Shenzhen Housing and Local Construction Bureau, SJG05-2011 Technical Code for Retaining and Protection of Excavations in Shenzhen City, China Architecture \& Building Press, Beijing, China, 2011, in Chinese. 